\title{
Macular and Subfoveal Choroidal Thickness before and after Phacoemulsification Using Optical Coherence Tomography in Diabetic and Non-Diabetic Patients
}

\author{
Mohamed A. El Malah, Ehab A. El sheikh, Mohamed B. El lakany
}

Department of ophthalmology, Faculty of Medicine, Al-Azhar University, Cairo, Egypt

Corresponding author: Mohamed B. El Lakany; Mobile: (+20) 1008363992; Email: dr_7amada2012@yahoo.com

\begin{abstract}
Introduction: Cataract surgery by phacoemulsification is an invasive procedure that has become the most common intraocular surgery and usually improves the visual outcome. However, it is an inflammatory process to the eye and in many cases can lead to worsening of pre-existing retinal diseases such as diabetic macular edema or development of new diseases such as Irvine-Gass syndrome. This inflammatory response is mostly induced by the release of prostaglandins.
\end{abstract}

Objective: The aim of this study was to evaluate the effect of uneventful phacoemulsification on the morphology and thickness of the macula and the choroid.

Patients and Methods: In 30 eyes from 30 patients (15 non-diabetic and 15 diabetic), central retinal macular thickness, and subfoveal choroidal thickness, were measured preoperatively and one month and three months after phacoemulsification using optical coherence tomography.

Results: In non-diabetic patients, central macular thickness was $202.80 \pm 22.39 \mu \mathrm{m}$ before phaco and $216.27 \pm 23.97 \mu \mathrm{m}$ after 1 month and $208.13 \pm 23.59 \mu \mathrm{m}$ after 3 months while Subfoveal choroidal thickness was $203.73 \pm 28.66$ before surgery and $218.80 \pm 31.09$ after 1 month and 209.20 \pm 30.63 after 3 months. In diabetic patients central macular thickness was $233.33 \pm 12.74$ before surgery and $253.27 \pm 15.89$ after 1 month and $246.93 \pm 22.39$ after 3 months while subfoveal choroidal thickness was $233.80 \pm 24.14$ before surgery and $252.80 \pm 26.59$ after 1 month and $243.47 \pm 24.45$ after 3 months.

Conclusion: Uncomplicated phacoemulsification induces non pathologic increases in subfoveal choroidal thickness and macular thickness probably due to the inflammatory effect of the surgery but it decreases nearly to normal after 3 months; however these changes are not accompanied by significant decrease in visual acuity.

Keywords: Phacoemulsification, macular thickness, choroidal thickness, diabetes, optical coherence tomography.

\section{INTRODUCTION}

Cataracts are the main cause of poor vision in older people. The removal of white water using lens emulsification surgery is one of the most common eye surgery operations (1). Choroid, the highest blood circulation in the human body, consists of blood vessels, connective tissues, nerves, melanocytes and extracellular fluid. Many analyze and research suggest that even non-complex emulsification leads to choroid disorders, especially an increase in chorionic thickness ${ }^{(2,3)}$. Pseudophakic cystoid macular edema (PCME) is the most common cause of low vision after cataract surgery. The peak occurs after about 4 to 6 weeks of surgery. These inflammatory effects of surgery may be associated with subclinical changes reported in non-active cataract surgery and may also be associated with pathological events such as IrvinGass syndrome. In honor of S. Rodman Irvine and J. Donald M. Gass ${ }^{(4)}$.

The exact pathogenesis of PCME remains unknown and is likely to be multifactorial. Indeed, many factors have been proposed such as vascular instability, vitreomacular traction, ocular hypotony, and UV light damage. However, postoperative inflammation appears to play a major role in its development. The surgical procedure releases inflammatory mediators, such as prostaglandins, leukotrienes, and cytokines, which lead to the breakdown of the blood-aqueous barrier and of the blood-retinal barrier ${ }^{(5)}$.
Optical coherence tomography (OCT) is a non invasive method that evaluates biological tissues by in vivo imaging. Since its introduction, OCT has undergone several improvements and revolutionized the diagnostic, monitoring, and therapeutic approaches to many retinal diseases and glaucoma. Computerized algorithms can be used on the highresolution images obtained by modern OCT devices to identify and measure the thicknesses of discrete retinal layers, including the retinal nerve fiber layer (RNFL), macular ganglion cell complex (GCC), and choroid $^{(6,7)}$.

Because cataract surgery has an inflammatory effect to the eye, several studies investigated the possibility that it may lead to an increase in the choroidal and retinal thickness at the posterior pole and that this eventual increase in choroidal thickness may be related to the changes in retinal macular thickness ${ }^{(8,9)}$. The subfoveal choroidal thickness (SFCT) is measured vertically, at the fovea, from the outer surface of the hyperreflective line ascribed to the retinal pigment epithelium (RPE) to the hyperreflective line of the inner sclera border ${ }^{(10)}$.

Diabetes is a metabolic disease affecting the systemic vasculature. Although the principal changes in diabetic eyes usually occur in the retinal vasculature, additional changes can be also observed in the choroidal layer; an important vascular tissue that supplies blood to the outer retina ${ }^{(11)}$. 
Histologic studies of diabetic eyes showed increased tortuosity, focal vascular dilation or narrowing, and the formation of sinus like structures between the choroidal lobules. Also, in some advanced cases, luminal narrowing of the capillaries, capillary dropout, and focal scarring ${ }^{(\mathbf{1 2})}$.

The aim of this study was to evaluate the effect of uneventful phacoemulsification on the morphology and thickness of the macula and the choroid.

\section{PATIENTS AND METHODS}

This randomized prospective study included a total of 30 eyes of 30 patients having immature senile cataract that were submitted for phacoemulsification, attending at Department of Ophthalmology, Faculty of Medicine, AlAzhar (Al-azhar) University Hospitals, Cairo, Egypt. Approval of the ethical committee and a written informed consent from all the subjects were obtained. This study was conducted between July 2018 and January 2019.

Inclusion criteria: Age (40-75), Patients medical history (15 diabetic type 2/ 15 non-diabetic), Cataractous patients and Normal macular thickness.
Exclusion criteria: Media opacity that prevent adequate OCT such as dense cataract, patients with glaucoma, Central foveal thickness $>250 \mu \mathrm{m}$, patients with history of photocoagulation and Patients with vitreoretinal pathology such as vitreomacular traction.

\section{Statistical Analysis}

Recorded data were analyzed using the statistical package for social sciences, version 20.0 (SPSS Inc., Chicago, Illinois, USA). Quantitative data were expressed as mean \pm standard deviation (SD). Qualitative data were expressed as frequency and percentage.

\section{RESULTS}

Thirty eyes from 30 patients were included in the study (15 nondiabetic group A and 15 diabetic group B). There were no intraoperative complications. OCT scans were done before and one month and three months following cataract surgery.

The results of the present study are demonstrated in the following tables.

Table (1): Comparison between group A: None DM and group B: DM according to demographic data.

\begin{tabular}{|c|c|c|c|c|c|}
\hline \multicolumn{2}{|c|}{ Demographic data } & $\begin{array}{c}\text { Group A: Non } \\
\text { DM }(n=15)\end{array}$ & $\begin{array}{c}\text { Group B: DM } \\
(n=15))\end{array}$ & $t / x 2 \#$ & p-value \\
\hline \multirow{2}{*}{ Age (years) } & Mean \pm SD & $60.73 \pm 5.54$ & $62.40 \pm 5.33$ & \multirow{2}{*}{0.706} & \multirow{2}{*}{0.408} \\
\hline & Range & 46_67 & 50_70 & & \\
\hline \multirow{2}{*}{ Side } & LT. & $7(46.7 \%)$ & $6(40.0 \%)$ & \multirow{2}{*}{$0.136 \#$} & \multirow{2}{*}{0.713} \\
\hline & RT. & $8(53.3 \%)$ & $9(60.0 \%)$ & & \\
\hline \multirow{2}{*}{ gender } & Female & $11(73.3 \%)$ & $11(73.3 \%)$ & \multirow{2}{*}{$0.000 \#$} & \multirow{2}{*}{1.000} \\
\hline & Male & $4(26.7 \%)$ & $4(26.7 \%)$ & & \\
\hline
\end{tabular}

t-Independent Sample t-test; \# $\mathrm{x}^{2}$ : Chi-square test, p-value >0.05 NS

This table shows no statistically significant difference between groups according to demographic data.

Table (2): Comparison between group A: None DM and group B: DM according to visual acuity.

\begin{tabular}{|c|c|c|c|c|c|}
\hline \multicolumn{2}{|l|}{ Visual Acuity } & $\begin{array}{c}\text { Group A: Non } \\
\text { DM }(n=15)\end{array}$ & $\begin{array}{c}\text { Group B: DM } \\
(n=15))\end{array}$ & t-test & p-value \\
\hline Baseline & $\begin{array}{l}\text { Mean } \pm S D \\
\text { Range }\end{array}$ & $\begin{array}{c}1.05 \pm 0.34 \\
0.6 \_1.6\end{array}$ & $\begin{array}{c}0.91 \pm 0.20 \\
0.6 \_1.2\end{array}$ & 1.733 & 0.199 \\
\hline $\begin{array}{l}\text { 1month post- } \\
\text { operative }\end{array}$ & $\begin{array}{l}\text { Mean } \pm \text { SD } \\
\text { Range }\end{array}$ & $\begin{array}{c}0.49 \pm 0.18 \\
0.2 \_0.8\end{array}$ & $\begin{array}{c}0.57 \pm 0.21 \\
0.2 \_0.8\end{array}$ & 1.024 & 0.320 \\
\hline $\begin{array}{l}\text { 3months post- } \\
\text { operative }\end{array}$ & $\begin{array}{l}\text { Mean } \pm S D \\
\text { Range }\end{array}$ & $\begin{array}{c}0.43 \pm 0.16 \\
0.2 \_0.6\end{array}$ & $\begin{array}{c}0.55 \pm 0.23 \\
0.2 \_1\end{array}$ & 3.159 & 0.086 \\
\hline $\begin{array}{l}\text { Change baseline } \\
\text { \& 1month post- } \\
\text { operative }\end{array}$ & $\begin{array}{l}\text { Mean } \pm \text { SD } \\
\text { Range }\end{array}$ & $\begin{array}{c}-0.55 \pm 0.27 \\
-1.1 \_-0.1\end{array}$ & $\begin{array}{c}-0.35 \pm 0.12 \\
-0.5 \_-0.1\end{array}$ & 7.265 & $0.012 *$ \\
\hline $\begin{array}{l}\text { Change baseline } \\
\text { \& 3months post- } \\
\text { operative }\end{array}$ & $\begin{array}{l}\text { Mean } \pm \text { SD } \\
\text { Range }\end{array}$ & $\begin{array}{c}-0.62 \pm 0.31 \\
-1.3 \_-0.3\end{array}$ & $\begin{array}{c}-0.36 \pm 0.15 \\
-0.6 \_-0.1\end{array}$ & 8.552 & $0.007 *$ \\
\hline
\end{tabular}

t-Independent Sample t-test;

p-value $>0.05 \mathrm{NS} ; *$ p-value $<0.05 \mathrm{~S}$

This table shows statistically significant difference between groups according to visual acuity change baseline $\& 1$ month post-operative (was better in group A than group B) and change baseline \& 3 months post-operative(was better in group A than group B). 
Mohamed El Malah et al.

Table (3): Comparison between group A: None DM and group B: DM according to IOP (mmHg).

\begin{tabular}{|c|c|c|c|c|c|}
\hline \multicolumn{2}{|l|}{ I.O.P (mmHg) } & $\begin{array}{c}\text { Group A: Non } \\
\text { DM }(n=15)\end{array}$ & $\begin{array}{c}\text { Group B: DM } \\
(n=15))\end{array}$ & t-test & p-value \\
\hline \multirow[b]{2}{*}{ Baseline } & Mean \pm SD & $16.53 \pm 1.88$ & $15.93 \pm 2.34$ & \multirow{2}{*}{0.597} & \multirow{2}{*}{0.446} \\
\hline & Range & $13 \_20$ & $12 \_20$ & & \\
\hline \multirow{2}{*}{ 1month post-operative } & Mean \pm SD & $15.13 \pm 1.85$ & $15.13 \pm 2.47$ & \multirow{2}{*}{0.000} & \multirow{2}{*}{1.000} \\
\hline & Range & $12 \_18$ & 11_18 & & \\
\hline \multirow{2}{*}{ 3months post-operative } & Mean \pm SD & $15.07 \pm 1.67$ & $15.00 \pm 1.73$ & \multirow{2}{*}{0.012} & \multirow{2}{*}{0.915} \\
\hline & Range & 12_18 & $12 \_18$ & & \\
\hline \multirow{2}{*}{$\begin{array}{l}\text { Change baseline \& } \\
\text { 1month post-operative }\end{array}$} & Mean \pm SD & $-1.40 \pm 0.91$ & $-0.80 \pm 1.37$ & \multirow{2}{*}{1.989} & \multirow{2}{*}{0.169} \\
\hline & Range & $-2 \_1$ & $-2 \_3$ & & \\
\hline \multirow{2}{*}{$\begin{array}{l}\text { Change baseline \& } \\
\text { 3months post-operative }\end{array}$} & Mean \pm SD & $-1.47 \pm 0.99$ & $-0.93 \pm 1.16$ & \multirow[b]{2}{*}{1.829} & \multirow[b]{2}{*}{0.187} \\
\hline & Range & $-3 \_1$ & $-2 \_1$ & & \\
\hline
\end{tabular}

t-Independent Sample t-test;

p-value >0.05 NS;

This table shows no statistically significant difference between groups according to IOP (mmHg).

Table (4): Comparison between group A: Non DM and group B: DM according to central macular thickness (micron).

\begin{tabular}{|c|c|c|c|c|c|}
\hline \multicolumn{2}{|c|}{$\begin{array}{c}\text { Central Macular Thickness } \\
\text { (micron) }\end{array}$} & $\begin{array}{c}\text { Group A: Non } \\
\text { DM }(n=15) \\
\end{array}$ & $\begin{array}{c}\text { Group B: DM } \\
(n=15))\end{array}$ & t-test & p-value \\
\hline \multirow{2}{*}{ Baseline } & Mean \pm SD & $202.80 \pm 22.39$ & $233.33 \pm 12.74$ & \multirow{2}{*}{21.079} & \multirow{2}{*}{$<0.001 * *$} \\
\hline & Range & 160_246 & 201_249 & & \\
\hline \multirow{2}{*}{$\begin{array}{l}\text { 1month post- } \\
\text { operative }\end{array}$} & Mean \pm SD & $216.27 \pm 23.97$ & $253.27 \pm 15.89$ & \multirow{2}{*}{24.818} & \multirow{2}{*}{$<0.001 * *$} \\
\hline & Range & 170_268 & 217_280 & & \\
\hline \multirow{2}{*}{$\begin{array}{l}\text { 3months post- } \\
\text { operative }\end{array}$} & Mean \pm SD & $208.13 \pm 23.59$ & $246.93 \pm 22.39$ & \multirow{2}{*}{21.351} & \multirow{2}{*}{$<0.001 * *$} \\
\hline & Range & 162_254 & 209_310 & & \\
\hline \multirow{2}{*}{$\begin{array}{l}\text { Change baseline \& } \\
\text { 1month post- } \\
\text { operative }\end{array}$} & Mean \pm SD & $13.47 \pm 3.83$ & $19.93 \pm 4.13$ & \multirow[b]{2}{*}{19.749} & \multirow[b]{2}{*}{$<0.001 * *$} \\
\hline & Range & 6_22 & 15_31 & & \\
\hline \multirow{2}{*}{$\begin{array}{l}\text { Change baseline \& } \\
\text { 3months post- } \\
\text { operative }\end{array}$} & Mean \pm SD & $5.33 \pm 2.38$ & $13.60 \pm 13.56$ & \multirow{2}{*}{5.405} & \multirow{2}{*}{$0.028^{*}$} \\
\hline & Range & 2_10 & 6_61 & & \\
\hline
\end{tabular}

This table shows statistically significant difference between groups according to central macular thickness (central macular thickness increased in group B more than group A).

Table (5): Comparison between group A: Non DM and group B: DM according to subfoveal choroidal thickness (micron).

\begin{tabular}{|c|c|c|c|c|c|}
\hline \multicolumn{2}{|c|}{$\begin{array}{l}\text { Subfoveal choroidal thickness } \\
\text { (micron) }\end{array}$} & \multirow{3}{*}{$\begin{array}{c}\text { Group A: Non } \\
\text { DM }(\boldsymbol{n}=\mathbf{1 5}) \\
203.73 \pm 28.66 \\
140 \_260 \\
\end{array}$} & \multirow{3}{*}{$\begin{array}{c}\text { Group B: DM } \\
(\boldsymbol{n}=\mathbf{1 5})) \\
233.80 \pm 24.14 \\
204 \_270\end{array}$} & \multirow{3}{*}{$\begin{array}{l}\text { t-test } \\
9.659\end{array}$} & \multirow{3}{*}{\begin{tabular}{|l} 
p-value \\
$0.004^{*}$
\end{tabular}} \\
\hline & Mean \pm SD & & & & \\
\hline Baselıne & Range & & & & \\
\hline \multirow{2}{*}{ 1month post-operative } & Mean \pm SD & $218.80 \pm 31.09$ & $252.80 \pm 26.59$ & \multirow{2}{*}{10.362} & \multirow{2}{*}{$0.003 *$} \\
\hline & Range & 151_284 & 221_295 & & \\
\hline \multirow{2}{*}{ 3months post-operative } & Mean \pm SD & $209.20 \pm 30.63$ & $243.47 \pm 24.45$ & \multirow{2}{*}{11.467} & \multirow{2}{*}{$0.002 *$} \\
\hline & Range & $144 \_276$ & $212 \_284$ & & \\
\hline \multirow{2}{*}{$\begin{array}{l}\text { Change baseline } \& \\
\text { 1month post-operative }\end{array}$} & Mean \pm SD & \multirow{2}{*}{$\begin{array}{c}15.07 \pm 3.73 \\
11 \_24\end{array}$} & \multirow{2}{*}{$\begin{array}{c}19.00 \pm 5.21 \\
11 \_29\end{array}$} & \multirow{2}{*}{5.651} & \multirow{2}{*}{$0.025^{*}$} \\
\hline & Range & & & & \\
\hline \multirow{2}{*}{$\begin{array}{l}\text { Change baseline } \& \\
\text { 3months post-operative }\end{array}$} & Mean \pm SD & \multirow{2}{*}{$\begin{array}{c}5.47 \pm 3.20 \\
3 \_16\end{array}$} & \multirow{2}{*}{$\begin{array}{l}9.67 \pm 6.38 \\
3 \_29\end{array}$} & \multirow{2}{*}{5.195} & \multirow{2}{*}{$0.030 *$} \\
\hline & Range & & & & \\
\hline
\end{tabular}

This table shows statistically significant difference between groups according to subfoveal choroidal thickness (micron) (subfoveal choroidal thickness increased in group B more than group A). 
Table (6): The extent of the difference over the periods through Visual Acuity, I.O.P (mmhg), Central Macular Thickness (micron) and Subfoveal choroidal thickness (micron) in group A: Non DM.

\begin{tabular}{|l|c|c|c|c|c|}
\hline $\begin{array}{l}\text { Group A: Non DM } \\
\text { (n=15) }\end{array}$ & Baseline & After 1m & After 3m & ANOVA & p-value \\
\hline Visual Acuity & $1.05 \pm 0.34$ & $0.49 \pm 0.18$ & $0.43 \pm 0.16$ & 7.808 & $<0.001^{* *}$ \\
\hline I.O.P (mmhg) & $16.53 \pm 1.88$ & $15.13 \pm 1.85$ & $15.07 \pm 1.67$ & 5.735 & $<0.001^{* *}$ \\
\hline $\begin{array}{l}\text { Central Macular } \\
\text { Thickness (micron) }\end{array}$ & $202.80 \pm 22.39$ & $216.27 \pm 23.97$ & $208.13 \pm 23.59$ & -8.677 & $<0.001 * *$ \\
\hline $\begin{array}{l}\text { Subfoveal choroidal } \\
\text { thickness (micron) }\end{array}$ & $203.73 \pm 28.66$ & $218.80 \pm 31.09$ & $209.20 \pm 30.63$ & -6.608 & $<0.001 * *$ \\
\hline
\end{tabular}

This table shows highly statistically significant difference between periods through Visual Acuity, I.O.P (mmhg), Central Macular Thickness (micron) and Subfoveal choroidal thickness (micron) in group A (Non DM).

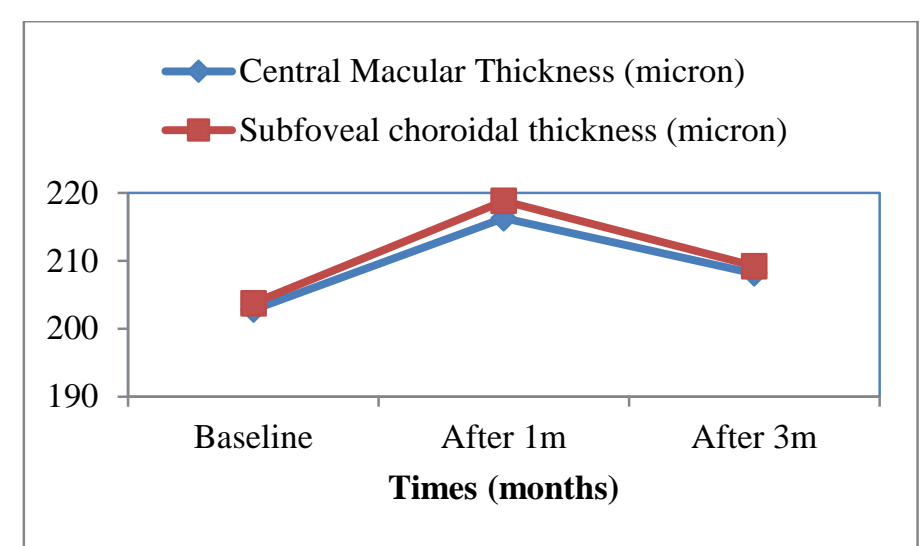

Figure (1): Line shows the extent of the difference in Central Macular Thickness (micron) and Subfoveal choroidal thickness (micron) in group A: Non DM through follow up period.

Table (7): The extent of the difference in Visual Acuity, I.O.P (mmhg), Central Macular Thickness (micron) and Subfoveal choroidal thickness (micron) in group B: DM through follow up period.

\begin{tabular}{|l|c|c|c|c|l|}
\hline Group B: DM (n=15) & Baseline & $\begin{array}{c}\text { 1month post- } \\
\text { operative }\end{array}$ & $\begin{array}{c}\text { 3months post- } \\
\text { operative }\end{array}$ & ANOVA & p-value \\
\hline Visual Acuity & $0.91 \pm 0.20$ & $0.57 \pm 0.21$ & $0.55 \pm 0.23$ & 9.000 & $<0.001^{* *}$ \\
\hline I.O.P (mmhg) & $15.93 \pm 2.34$ & $15.13 \pm 2.47$ & $15.00 \pm 1.73$ & 3.108 & $0.008^{*}$ \\
\hline $\begin{array}{l}\text { Central Macular } \\
\text { Thickness (micron) }\end{array}$ & $233.33 \pm 12.74$ & $253.27 \pm 15.89$ & $246.93 \pm 22.39$ & -3.883 & $0.002^{*}$ \\
\hline $\begin{array}{l}\text { Subfoveal choroidal } \\
\text { thickness (micron) }\end{array}$ & $233.80 \pm 24.14$ & $252.80 \pm 26.59$ & $243.47 \pm 24.45$ & -5.871 & $<0.001 * *$ \\
\hline
\end{tabular}

F-One Way Analysis

*p-value $<0.05 \mathrm{~S} ; * *$ p-value $<0.001 \mathrm{HS}$

This table shows statistically significant difference in Visual Acuity, I.O.P (mmhg), Central Macular Thickness (micron) and Subfoveal choroidal thickness (micron) in group B: DM through follow up period. 
Mohamed El Malah et al.

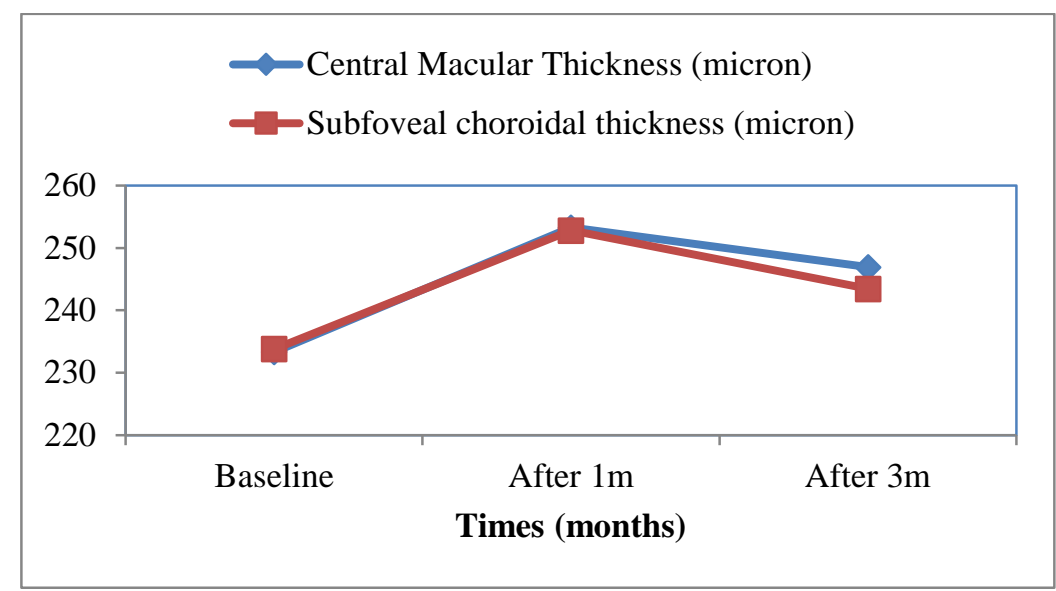

Figure (2): Line shows the extent of the difference in Central Macular Thickness (micron) and Subfoveal choroidal thickness (micron) in group B: DM through follow up period.

\section{DISCUSSION}

Another study showed that lenticular fragments could lead to a breakdown of the inner blood-retinal barrier ${ }^{(16)}$. These inflammatory consequences of surgery may be associated with the subclinical macular changes that have been reported in uneventful cataract surgery and may also be related to pathologic events such as IrvineGass syndrome ${ }^{(14-17)}$.

Diabetes is a metabolic disease affecting the systemic vasculature. Although the principal changes in diabetic eyes usually occur in the retinal vasculature, additional changes can be also observed in the choroidal layer; an important vascular tissue that supplies blood to the outer retina ${ }^{(19)}$.

In addition, studies using indocyanine green angiography showed filling delay or defects in the choriocapillaris, saccular dilatations, microaneurysms in the choriocapillaris, and choroidal neovascularization $(20,21)$.

Previously, the full thickness of the choroid could not be seen in most eyes because of scattering and insufficient light penetration beyond the retinal pigment epithelium, and signal strength roll-off distal to the zerodelay line. Decreased signal strength posterior to the retinal pigment epithelium is compensated by the image enhancement software, which enables visualization of the border where choroidal tissue meets sclera and allows CT measurements to be performed ${ }^{(22-26)}$.

Differences among different studies might be due to individual variation in device characteristics such as wavelength, eye tracking method, and averaging software or due to differences of participant profiles such as ethnicity, age, and refractive error ${ }^{(27)}$.

Because cataract surgery is an inflammatory process to the eye, we investigated the possibility that it may lead to an increase in the choroidal and macular thickness in uneventful phacoemulsification.

In our prospective study OCT scanning of 30 eyes (15 diabetic and 15 non diabetic) undergoing cataract extraction by phacoemulsification were done using OCT, the choroidal and macular changes were evaluated before and at one month and at three months after cataract extraction.

We found that there was significant increase in macular thickness following cataract extraction by phacoemulsification in non diabetic patients (216.27 \pm 23.97$)$ after 1 month then decreased to (208.13 \pm 23.59$)$ after 3 months p-value (0.001), in diabetic patients there was more significant increase in macular thickness $(253.27 \pm 15.89)$ after 1 month then decreased to (246.93 \pm 22.39$)$ after 3 months p-value (0.002).

In a study by Cagini $\boldsymbol{e t}$ al. ${ }^{(27)}$ performed on 62 eyes they measured macular thickness before and at 3 , $6,12,20$, and 28 weeks after surgery using the OCT technique, they found during the follow-up that there is a statistically significant increase in the macular volume at the 12th week after surgery. Two eyes developed clinically significant macular edema and there was no correlation between macular changes and best corrected visual acuity (BCVA) or ultrasound time.

Another study by Burkhard et al. ${ }^{(28)}$ studied macular thickness after uneventful cataract surgery on 33 eyes with follow up OCT 1 day, 1 week and 6 weeks postoperatively ocular axial length, anterior chamber depth, phacotime and energy were documented. There was a significant increase in the mean foveal thickness 1 day, 1 week and 6 weeks $(1$ day: $+10.66 \pm 20.8 \mu \mathrm{m}$, $\mathrm{P}=0,026 ; 1$ week: $+15.23 \pm 19.7 \mu \mathrm{m} ; 6$ weeks: $+17.33 \pm 14.81 \mu \mathrm{m}, \mathrm{P}<0.001)$.

They reached a conclusion that after cataract surgery, a mild increase in foveal thickness without impact on visual acuity could be observed. They explained that this increase may be due to both subclinical changes and due to influence of changes in media opacity on the measurement technique. Surgical and biometric parameters such as phacotime and energy and axial length did not correlate to the degree of macular thickening ${ }^{(29)}$.

In our study we found that following cataract extraction there was an increase in the mean choroidal thickness in non diabetic patients $218.80 \pm 31.09$ after 1 month and then decreased to $209.20 \pm 30.63$ after 3 
months $\mathrm{p}$-value $(<0.001)$, in diabetic patients there was an increase in the mean choroidal thickness $252.80 \pm 26.59$ after 1 month then decreased to $243.47 \pm 24.45$ after 3 months p-value $(<0.001)$.

These results are similar to the study done by Alexandra et al. ${ }^{(29)}$ which was performed on 115 eyes , they measured the subfoveal choroidal thickness before and 1 day, 7 days, 1 month, 3 months, after surgery using the EDI-OCT technique .it showed that subfoveal choroidal thickness significantly increased at the seventh day postoperatively and reached a peak after one month of the surgery with a mean value of 232 $\pm 76 \mu \mathrm{m}$ at $\mathrm{D} 1(\mathrm{P}<0.001), 237 \pm 78 \mu \mathrm{m}$ at $\mathrm{M} 1(\mathrm{P}<0.001)$, and $232 \pm 76 \mu \mathrm{m}$ at $\mathrm{M} 3(\mathrm{P}<0.001)^{(17)}$.

While Manuel et al. ${ }^{(17)}$ performed a recent prospective study on 14 eyes of 14 patients, it showed that there were no significant changes in choroidal thickness in the submacular areas one month after surgery. In vertical scans, there were no significant increase in choroidal thickness $(+4.21 \pm 20.2$ $\mu \mathrm{m} ; P=0.47)$ whilst in horizontal scans a nonsignificant decrease was recorded $(-9.11 \pm 39.59 \mu \mathrm{m} ; P=0.41)$. There was a statistically significant increase in mean macular thickness at one month. In horizontal scans, the mean increase was $+8.67 \pm 6.75 \mu \mathrm{m}(P<0.001)$, and in vertical scans, the mean increase was $+8.80 \pm 7.07$ $\mu \mathrm{m}(P=0.001)$.

However, Limitations to the study were the low number of patients included ${ }^{(15)}$.

Phacoemulsification seems to be able to induce morphologic changes in the choroid layers. Xu et al. ${ }^{(15)}$ have disclosed interesting results on the effect of cataract surgery on the choroid. They have investigated the expression of genes that might affect the bloodretinal barriers, including cytokine IL-1b, chemokines CCL2 and SDF-1, and growth factors FGF and VEGF, in the retina and the $\mathrm{RPE} /$ choroid of mice undergoing extracapsular lens extraction. They found that the expression of these genes was markedly upregulated in the retina and in the choroid. However, the level of upregulation was less elevated in the RPE/choroid than in the retina and was delayed in the RPE/choroid, occurring 24 hours post operation versus 30 minutes in the retina. They also found that the protein IL-1b, which is a pro-inflammatory cytokine, was strongly detected in the ganglion cell layer, inner cell layer, and in the choroid of operated mice eyes ${ }^{(30)}$.

However, how cataract surgery induces retinal and choroidal inflammation is not understood. It is known that the surgical trauma induces releases of prostaglandins in the aqueous humor that causes a disruption of the blood aqueous barrier. This results in the accumulation of other inflammatory mediators such as endotoxin, immune complex, and cytokines in the aqueous humor ${ }^{(31)}$.

These inflammatory mediators diffuse into the vitreous cavity to reach the retina, where they are responsible for a rupture of the inner blood-retinal barrier resulting in another cascade of inflammatory mediators secretion together with an increased permeability from the perifoveal capillaries ${ }^{(31)}$.

The outer blood-retinal barrier has also been shown to be disrupted as a consequence of post cataract surgery inflammation ${ }^{(32)}$.

Also in our study there was no significant correlation between macular and choroidal thickness changes and intraoperative factors (length of surgery, effective phaco time, phaco energy) in 2 groups.

\section{CONCLUSION}

Uncomplicated phacoemulsification induces a non-pathologic significant changes in retinal macular thickness and choroidal thickness probably due to the inflammatory effects of the surgery. At present, the clinical significance of this increase in macular and choroidal thickness in diabetic patients mildly higher than non-diabetic patients. Phacoemulsification is a very frequent procedure and it's long-term effect on retinal and choroidal functions is not known.

\section{RECOMMENDATIONS}

Our study was limited by a small sample size, and short follow up period however, we were able to detect and confirm the previously described macular and choroidal changes.

Another study with longer follow up period is recommended to know the long term effect of these changes on visual acuity and if these changes are permanent or not.

\section{REFERENCES}

1. Chu C, Johnston R, Buscombe C et al. (2016): Risk factors and incidence of macular edema after cataract surgery: a data- base study of 81984 eyes. Ophthalmology, 123(2): 316-23.

2. Agrawal R, Gupta P, Tan KA et al. (2016): Choroidal vascularity index as a measure of vascular status of the choroid: measurements in healthy eyes from a population-based study. Sci Rep., 6:88-90.

3. Cheong KX and Tan CS (2015): Long-term increase in subfoveal choroidal thickness after surgery for senile cataracts. Am J Ophthalmol., 159(3):608-9.

4. Agange $\mathbf{N}$ and Mosaed S (2010): Prostaglandin-induced cystoid macular edema following routine cataract extraction. J Ophthalmol., 2010:690-7.

5. Browning D, Glassman A, Aiello L et al. (2007): Diabetic Retinopathy Clinical Research Network. Relationship between optical coherence tomography measured central retinal thickness and visual acuity in diabetic macular edema. Ophthalmology, 114:525-36.

6. Shao L, Xu L, Chen CX et al. (2013): Reproducibility of subfoveal choroidal thickness measurements with enhanced depth imaging by spectral-domain optical coherence tomography. Invest Ophthalmology Vis Sci., $54: 230-33$. 
7. Pierru A, Carles M, Gastaud $P$ et al. (2014): Measurement of subfoveal choroidal thickness after cataract surgery in enhanced depth imaging optical coherence tomography. Invest Ophthalmol Vis Sci., 55(8):4967-74.

8. Spaide RF, Koizumi H and Pozzoni MC (2008): Enhanced depth imaging spectral-domain optical coherence tomography. Am J Oph- thalmol., 146:496500.

9. Margolis R and Spaide RF (2009): A pilot study of enhanced depth imaging optical coherence tomography of the choroid in normal eyes. Am J Ophthalmol., 147:811-815.

10. Yılmaz T, Karci AA, Yilmaz İ et al. (2016): Long-term changes in subfoveal choroidal thickness after cataract surgery. Med Sci Monit., 22:1566-70

11. Cao J, McLeod S, Merges CA et al. (1998): Choriocapillaris degeneration and related pathologic changes in human diabetic eyes. Arch Ophthal Mol., 116(5): 589-97.

12. Melancia D, Vicente A, Cunha JP et al. (2016): Diabetic choroidopathy: a review of the current literature. Graefes Arch Clin Exp Ophthalmol., 25: 22-28.

13.Jaffe GJ, Burton TC, Kuhn E et al. (1992): Progression of non-proliferative diabetic retinopathy and visual outcome after extracapsular cataract extraction and intraocular lens implantation. Am J Ophthalmol., 114(4):448-56.

14. Kim SJ, Flach AJ and Jampol LM (2010): Nonsteroidal anti-inflammatory drugs in ophthalmology. Surv Ophthalmol., 55(2):108-33.

15.Xu H, Chen M, Forrester JV et al. (2011): Cataract surgery induces retinal pro-inflammatory gene expression and protein secretion. Invest Ophthalmol Vis Sci., 52(1):249-55.

16. Liu H, Demetriades AM, Xiao WH et al. (2004): Mouse model of post-surgical breakdown of the bloodretinal barrier. Curr Eye Res., 28(6):421-26.

17. Manuel SF, Nuno MG, Paulo FC et al. (2014): Choroidal and macular thickness changes induced by cataract surgery. Clin Ophthalmol., 8: 55-60.

18. Nickla DL and Wallman J (2010): The multifunctional choroid. Prog Retin Eye Res., 29: 144-68.

19. Weinberger D, Kramer M, Priel E et al. (1998): Indocyanine green angiographic findings in nonproliferative diabetic retinopathy. Am J Ophthalmol., 126: 238-47.

20.Shiragami C, Shiraga F, Matsuo T et al. (2002): Risk factors for diabeticchoroidopathy in patients with diabetic retinopathy. Graefes Arch Clin Exp Ophthalmol., 240: 436-42.

21. Hanyuda N, Akiyama H, Shimoda Y et al. (2017): Different Filling Patterns of the Choriocapillaris in Fluorescein and Indocyanine Green Angiography in Primate Eyes Under Elevated Intraocular Pressure. Invest Ophthalmol Vis Sci., 58(13):5856-5861.

22. Chen TC, Cense B, Miller JW et al. (2006): Histologic correlation of in vivo optical coherence tomography images of the human retina. Am J Ophthalmol., 141(6): 1165-8.

23. Manjunath V, Taha M, Fujimoto JG et al. (2010): Choroidal thickness in normal eyes measured using Cirrus HD optical coherence tomography. Am J Ophthalmol., 150: 325-9

24. Imamura Y, Fujiwara T, Margolis R et al. (2009): Enhanced depth imaging optical coherence tomography of the choroid in central serous chorioretinopathy. Retina, 29(10): 1469-73.

25. Regatieri CV, Branchini L, Carmody J et al. (2012): Choroidal thickness in patients with diabetic retinopathy analyzed by spectral-domain optical coherence tomography. Retina, 32: 563-8.

26. Shin JW, Yong US, Hee YC et al. (2012): Measurement of Choroidal Thickness in Normal Eyes Using 3D OCT1000 Spectral Domain Optical Coherence Tomography. Korean J Ophthalmol., 26(4): 255-9.

27. Cagini C, Fiore T, Iaccher B et al. (2009): Macular thickness measured by optical coherence tomography in a healthy population before and after uncomplicated cataract phacoemulsification surgery. Current Eye Research, 34(12): 1036-41.

28. Burkhard J, Christian O, Thomas K et al. (2009): Macular thickness measured by optical coherence tomography in a healthy population before and after uncomplicated cataract phacoemulsification surgery. Current Eye Research, 34(12): 1036-41.

29. Alexandra P, Michel Cs, Pierre G et al. (2014): Measurement of subfoveal choroidal thickness after cataract surgery in enhanced depth imaging optical coherence tomography. Invest Ophthalmol Vis Sci., 55: 4967- 74.

30. Miyake K, Ibaraki N (2002): Prostaglandins and cystoid macular edema. Survey Ophthalmol., 47: 20318.

31.Flach AJ (1998): The incidence, pathogenesis and treatment of cystoid macular edema following cataract surgery. Trans Am Ophthalmol Soc., 96: 557-34.

32. Tso MO, Shih CY (1977): Experimental macular edema after lens extraction. Invest Ophthalmol Vis Sci., 16(5):381-92. 